Identifying patterns in channel usage across the search, purchase and post-sales stages of shopping

\author{
Marta FRASQUET ${ }^{1}$, Alejandro MOLLÁ, Eugenia RUIZ \\ Department of Marketing, University of Valencia. Av. Tarongers, s/n, 46022 Valencia, Spain
}

Published in Electronic Commerce Research and Applications, Vol. 14, Issue 6, OctoberNovember 2015, pages 654-665. https://doi.org/10.1016/j.elerap.2015.10.002.

\begin{abstract}
:
Consumers today are using various channels to complete their purchase process. As shoppers pursue different goals at each stage of the process, channel choice may be explained by different drivers for search, purchase and post-sales activities. Our research framework is based on an extension of the TAM Model with the support of the Motivational Model, differentiating two types of motivations for channel usage: intrinsic and extrinsic. Moreover, we rely on transaction costs economics to explain different channel usage at each shopping stages and for different product categories. Lineal regression and cluster analysis are applied to data collected through a survey answered by 1,533 multichannel retail shoppers within two product categories (apparel and consumer electronics) in two countries (UK and Spain). Our findings show that segments with different usage patterns and motivations can be identified across the shopping process and that the drivers of channel usage are different depending on the stage of the buying process and the product category considered.
\end{abstract}

Keywords: purchase process; channel choice; retail; multichannel shoppers; segmentation; online shopping.

Acknowledgement: This research has been financed by the Spanish Ministry of Education and Science (Project ref.: EC02014-55881).

\footnotetext{
*Corresponding author. E-mail address: marta.frasquet@uv.es; Tel.: +34963828959; Department of Marketing, Facultat d'Economia, Av. Tarongers, s/n, 46022 Valencia, Spain
} 


\section{Identifying patterns in channel usage across the search, purchase and post-sales stages of shopping}

\section{Introduction}

With the growth of online selling, multichannel distribution has become a strategic priority for firms in every sector, particularly for brick-and-mortar retailers. Nonetheless, as Badrinarayanan et al. (2012) state, research on multichannel retailing is sparse and fragmented. A retailer that starts selling over the Internet faces increased and new forms of competition; as Shankar et al. (2003) put it, "a competing offer is just a few clicks away on the Internet" (p.41). Multichannel shoppers are defined as those that combine various channels to complete the purchase process; they may navigate the same retailer's channels or they may cross to other retailers' channels. In this scenario where customer switching costs are minimal, the retailer that does not integrate its channels correctly risks losing customers to competitors during the purchase process (Bendoly et al., 2005).

In the competitive multichannel environment retailers need to understand what drives the behaviour of multichannel shoppers, not only to keep customers but to also target the appropriate customers in channel migration campaigns. Often, retailers encourage customers to shop from different channels, as there is evidence that multichannel customers provide higher revenues (Venkatesan et al., 2007; Kushwaha and Shankar, 2007; Ansari et al. 2008; Kushwaha and Shankar, 2013) and are more loyal (Kumar and Venkatasan, 2005; Wallace et al., 2004). However, multichannel retail shoppers are not a homogeneous group (Thomas and Sullivan, 2005) and identifying segments differing in channel use is essential for retailers to implement a multichannel strategy. Rangaswamy and van Bruggen (2005) stress the need to have a clearer picture of what types of customers are shopping across channels and what drives channel preference. This research gap, related to identifying the drivers of the behaviour of channel-based segments, is also emphasized by Neslin et al. (2006), Zhang et al. (2010) and Dholakia et al. (2010).

Our paper is based on the belief that in order to understand multichannel shopper behaviour, it is necessary to take into consideration the stages of the purchase process. Early contributions, such as Alba et al. (1997) and Peterson et al. (1997), highlighted the need to investigate how consumers navigate across the Internet and conventional retail channels during the search and purchase stages. We identify a research gap in analyzing whether or not the drivers of channel choice are different for each purchase stage. Most papers investigate the drivers of channel choice strictly at the purchase stage, a few papers have integrated the search and purchase stages (e.g. Konuş et al., 2008 and Verhoef et al., 2007) but to our knowledge there is no research that includes the post-sales stage. Postsales activities include product returns, claims, and repair or maintenance services. After-sales activities play a critical role for retail companies as they are an opportunity to achieve customer satisfaction and retention (Cavalieri et al., 2007). Additionally, in online selling, offering a straightforward post-sales service is a means to reducing perceived risks and attracting online buyers (Huang et al., 2006). The need to investigate how consumers use channels for post-sales activities was strongly advised by Konuş et al. (2008).

Thus, the main contribution of our paper lies in analyzing the drivers of channel choice for the three main stages of the purchasing process: search, purchase and post-sales activities and to do so, adopting a segmentation approach to account for the diversity of behavioral patterns. The choice of drivers of channel choice is based on an extension of the Technology Acceptance Model (TAM) with the support of the Motivational Model. Thus, we consider channel usage is driven by two types of motivation, extrinsic (i.e. external rewards of using the Internet for shopping) and intrinsic (i.e. rewards related to the interaction with the Internet while shopping). The research design of our paper presents two additional contributions: first, we analyse and compare two different product categories: apparel as an example of experience goods, and consumer electronics as search goods, which are believed to have different shopping requirements; secondly, we collect data from two countries, i.e. Spain and Britain, which show different degrees of penetration of Internet use and analyse the differences in channel behaviour between them. 
The rest of the paper is structured as follows. In the next section we review the literature on the topic of multichannel consumer segmentation, present our research framework and discuss the drivers of multichannel shopping. In section 3 we explain the methodology of the empirical study. Section 4 contains the discussion of results, and section 5 the conclusions and implications of our research.

\section{Theoretical background}

\subsection{Segmentation of multichannel consumers}

Research on shopper typologies has a long tradition in retailing. There are a significant number of papers in this research area applied to offline retail formats (e.g. Bellenger et al., 1977; Bloch et al., 1994), which use segmentation criteria such as shopping motivations or mall/store attributes. At the beginning of the 2000s researchers became interested in segmenting online customers (e.g. Brengman et al., 2005). Most papers suggest that online shoppers have different motivations, attitudes, or loyalty patterns (e.g. Mathwick et al., 2001), but Ganesh et al. (2010) found more similarities than differences between online and offline shoppers.

Nowadays, it is difficult to draw a clear line separating online and offline shoppers and thus the interest has shifted to identifying typologies of multichannel consumers. Neslin and Shankar (2009) suggest a multichannel customer management decision framework that starts with customer analysis and identification of customer segments. They argue that customers differ in channel usage and segments formed on the basis of channel usage meet the criteria of being measurable, accessible, differentially responsive, actionable and substantial. According to Neslin and Shankar (2009) customers that differ in channel usage differ in other characteristics as well, and they challenge researchers to identify the most effective segmentation variables.

There are few papers that provide empirical evidence on segmentation of multichannel retail shoppers. Table 1 summarises the characteristics of those studies. Most of the papers form segments on the basis of channel choice or channel choice intention, while some include multiple measures of channel usage. There is considerable variety in the variables chosen to explain the segments. Channels' attributes, response to marketing communications, demographics and psychographics are the most frequently used variables. The variables used are of course related to the method employed: the studies based on companies' databases employ objective measures such as the channel of purchase, marketing communications, or demographics, while the studies based on surveys employ subjective variables such as consumer attitudes or psychographics. There are corresponding findings in the reviewed papers: the importance of the multichannel segment, with the trend of consumers moving online found by Knox (2005), the existence of a hard-core offline segment, the tendency to remain in the channel with which the consumer most familiar, or the use of the online channel for search and the store channel for purchase. Most of the papers investigate multichannel behaviour solely at the purchase stage, but Verhoef et al. (2007), Konuş et al. (2008), and Schröder and Zaharia (2008) investigate the search and purchase stages of the shopping process. The findings of these papers are mixed and will be discussed in the next section. 
Table 1. Empirical papers on multichannel retail shopper segmentation

\begin{tabular}{|c|c|c|c|c|c|c|c|}
\hline & Main aim & $\begin{array}{l}\text { Shopping } \\
\text { phase }\end{array}$ & Segmentation basis & Covariates & Method & Product category & Key findings \\
\hline $\begin{array}{l}\text { Keen et al. } \\
\text { (2004) }\end{array}$ & $\begin{array}{l}\text { Investigate intention } \\
\text { to purchase in } \\
\text { different channels. }\end{array}$ & Purchase & $\begin{array}{l}\text { Channel choice and } \\
\text { importance of channels } \\
\text { attributes: ease-of-use, } \\
\text { control, subjective } \\
\text { norm, attitude and price. }\end{array}$ & None & $\begin{array}{l}290 \text { shoppers } \\
\text { Conjoint experiment } \\
\text { Mall intercept survey } \\
\text { Ward and k-means } \\
\text { clustering }\end{array}$ & Electronics & $\begin{array}{l}\text { Identifiable segment with a } \\
\text { preference for shopping } \\
\text { online }\end{array}$ \\
\hline Knox (2005) & $\begin{array}{l}\text { Analyse the effect } \\
\text { of marketing } \\
\text { communications in } \\
\text { channel migration. }\end{array}$ & Purchase & $\begin{array}{l}\text { Purchasing } \\
\text { Channel choice } \\
\text { Spending amount }\end{array}$ & $\begin{array}{l}\text { Response to marketing } \\
\text { communications (catalogues } \\
\text { and emails). }\end{array}$ & $\begin{array}{l}\text { 1,819 shoppers } \\
140 \text { weeks database of a } \\
\text { retailer } \\
\text { Hidden Markov chain }\end{array}$ & n.a. & $\begin{array}{l}\text { Migration segment gradually } \\
\text { moving online } \\
\text { Hard-core offline segment }\end{array}$ \\
\hline $\begin{array}{l}\text { Thomas and } \\
\text { Sullivan (2005) }\end{array}$ & $\begin{array}{l}\text { Understand channel } \\
\text { choice over time to } \\
\text { design marketing } \\
\text { communications. }\end{array}$ & Purchase & Channel choice & $\begin{array}{l}\text { Price, product category, } \\
\text { distance to store, marketing } \\
\text { communications, previous } \\
\text { channel. }\end{array}$ & $\begin{array}{l}4,100 \text { customers of a retailer } \\
\text { One-year database } \\
\text { Latent class segmentation } \\
\text { Markov chain }\end{array}$ & $\begin{array}{l}11 \text { product } \\
\text { categories }\end{array}$ & $\begin{array}{l}\text { Two segments: catalog \& } \\
\text { Internet shoppers, and brick- } \\
\text { and-mortar shoppers. } \\
\text { High channel loyalty }\end{array}$ \\
\hline $\begin{array}{l}\text { Verhoef et al. } \\
\text { (2007) }\end{array}$ & $\begin{array}{l}\text { Understand research } \\
\text { shopping } \\
\text { phenomenon }\end{array}$ & $\begin{array}{l}\text { Search and } \\
\text { purchase }\end{array}$ & $\begin{array}{l}\text { Channel choice } \\
\text { intention for search and } \\
\text { purchase. }\end{array}$ & $\begin{array}{l}\text { Channel attributes for search } \\
\text { and purchase, channel attitudes } \\
\text { for search and purchase. }\end{array}$ & $\begin{array}{l}396 \text { consumers } \\
\text { Mail panel survey }\end{array}$ & $\begin{array}{l}\text { Loans, holidays, } \\
\text { books, computers, } \\
\text { clothing, appliances }\end{array}$ & $\begin{array}{l}\text { Low lock-in of Internet } \\
\text { channel and high cross- } \\
\text { channel synergy (search } \\
\text { online purchase at store) }\end{array}$ \\
\hline $\begin{array}{l}\text { Mc Goldrick et } \\
\text { al. (2007) }\end{array}$ & $\begin{array}{l}\text { Profile the } \\
\text { multichannel } \\
\text { shopper. }\end{array}$ & Purchase & $\begin{array}{l}\text { Frequency of channel } \\
\text { use } \\
\text { Channel preference } \\
\text { Expenditure by channel }\end{array}$ & $\begin{array}{l}\text { Channel perceived attributes, } \\
\text { shopping scenarios, sector, } \\
\text { demographics. }\end{array}$ & $\begin{array}{l}2,341 \text { shoppers } \\
\text { Mail survey } \\
\text { K-means clustering }\end{array}$ & $\begin{array}{l}\text { Grocery, clothes, } \\
\text { home entertainment }\end{array}$ & $\begin{array}{l}\text { Multichannel shopper } \\
\text { segment is substantial }\end{array}$ \\
\hline $\begin{array}{l}\text { Kushwaha and } \\
\text { Shankar (2007) }\end{array}$ & $\begin{array}{l}\text { Analyse the drivers } \\
\text { and consequences } \\
\text { of channel choice. }\end{array}$ & Purchase & Channel choice & $\begin{array}{l}\text { Demographics, shopping traits, } \\
\text { marketing efforts, product } \\
\text { category. }\end{array}$ & $\begin{array}{l}96 \text { million customers of } 750 \\
\text { retailers } \\
\text { Four-year database } \\
\text { Multinomial probit model }\end{array}$ & $\begin{array}{l}24 \text { product } \\
\text { categories }\end{array}$ & $\begin{array}{l}\text { Multichannel shoppers: } \\
\text { younger, more educated, buy } \\
\text { more categories, more } \\
\text { shopping experience, get } \\
\text { more marketing mailers. }\end{array}$ \\
\hline $\begin{array}{l}\text { Konuş et al. } \\
\text { (2008) }\end{array}$ & $\begin{array}{l}\text { Segment shoppers } \\
\text { and find covariates. }\end{array}$ & $\begin{array}{l}\text { Search and } \\
\text { purchase }\end{array}$ & $\begin{array}{l}\text { Attitudes towards } \\
\text { channels for search and } \\
\text { purchase. }\end{array}$ & $\begin{array}{l}\text { Psychographics (price } \\
\text { consciousness, loyalty, } \\
\text { enjoyment, time pressure, } \\
\text { motivation conform, } \\
\text { innovativeness), } \\
\text { demographics. }\end{array}$ & $\begin{array}{l}364 \text { consumers } \\
\text { Online panel survey } \\
\text { Latent class segmentation }\end{array}$ & $\begin{array}{l}\text { Mortgage, } \\
\text { insurance, holidays, } \\
\text { books, computers, } \\
\text { electronics, clothing }\end{array}$ & $\begin{array}{l}\text { Relevant segments: } \\
\text { multichannel enthusiasts, } \\
\text { store-focused. } \\
\text { Channel orientation similar } \\
\text { for different shopping stages. }\end{array}$ \\
\hline $\begin{array}{l}\text { Schröder and } \\
\text { Zaharia (2008) }\end{array}$ & $\begin{array}{l}\text { Explain multi- } \\
\text { channel behavior } \\
\text { through shopping } \\
\text { motives }\end{array}$ & $\begin{array}{l}\text { Search and } \\
\text { purchase }\end{array}$ & $\begin{array}{l}\text { Channel used for search } \\
\text { and for purchase }\end{array}$ & $\begin{array}{l}\text { Shopping motives: recreational } \\
\text { orientation, risk aversion, } \\
\text { convenience orientation, } \\
\text { independence orientation }\end{array}$ & $\begin{array}{l}525 \text { customers of a retailer } \\
\text { Telephone survey } \\
\text { Discriminant analysis }\end{array}$ & $\begin{array}{l}\text { Several categories } \\
\text { sold by the retailer } \\
\text { (e.g. apparel, toys } \\
\text { electronics) }\end{array}$ & $\begin{array}{l}\text { Most customers use the same } \\
\text { channel for one purchase } \\
\text { process, but use different } \\
\text { channels for different buying } \\
\text { processes }\end{array}$ \\
\hline
\end{tabular}




\subsection{Conceptual model}

Our research design tries to explain channel usage for each stage of shopping by looking at the variables that define channel-based segments. Our model is an extension of the TAM model with the support of the Motivational Model. The use of the Internet for shopping has been often explained with the TAM model developed by Davis (1989), which includes usefulness and ease-of-use as main determinants of the acceptance of a technology for developing a task. The parsimony and predictive power of TAM are its main strengths, but parsimony is also a limitation as there may be other variables instrumental for managers to promote the use of a technology. This limitation was acknowledged by the developers of the TAM model, who suggested additional variables to improve the understanding of the behaviour (e.g. Venkatesh et al., 2003). The Motivational Model (Deci and Ryan, 1987; Vallerand, 1997) has been used by some researchers to overcome the limitations of the TAM model to explain the acceptance of technology (Venkatesh, 2000; Van der Heijden, 2004), particularly the online channel (Teo et al., 1999; Shang et al., 2005). An extrinsically motivated consumer will use the online channel to achieve rewards external to the system, while an intrinsically motivated shopper will shop online driven by the benefits derived from the interaction with the Internet.

The idea of different channel usage across the shopping process was in the early conceptual contributions of Peterson et al. (1997) and Alba et al. (1997), who analysed the advantages of each channel for different stages of the buying process. We rely on transaction costs economics to expect that the drivers of channel usage will act differently at each stage of shopping. There are different types of transaction costs involved across the purchase process and the online channel lowers the costs at the search stage but raises the examination, payment and post-sales costs. Balasubramanian et al. (2005) developed a model of product and process utilities that analysed channel choice considering three stages of shopping: forming a consideration set, product evaluation and purchasing. They found that for the first two stages the Internet is particularly useful as it lowers information-search costs. For purchasing, they suggested that the online channel will be chosen when consumers want to minimize transaction costs, and the offline channel when there is perceived risk and a preference for immediate consumption. Some other researchers (e.g.: Liang and Huang, 1998; Teo and Yu, 2005) have explicitly applied transaction costs economics to explain online purchasing.

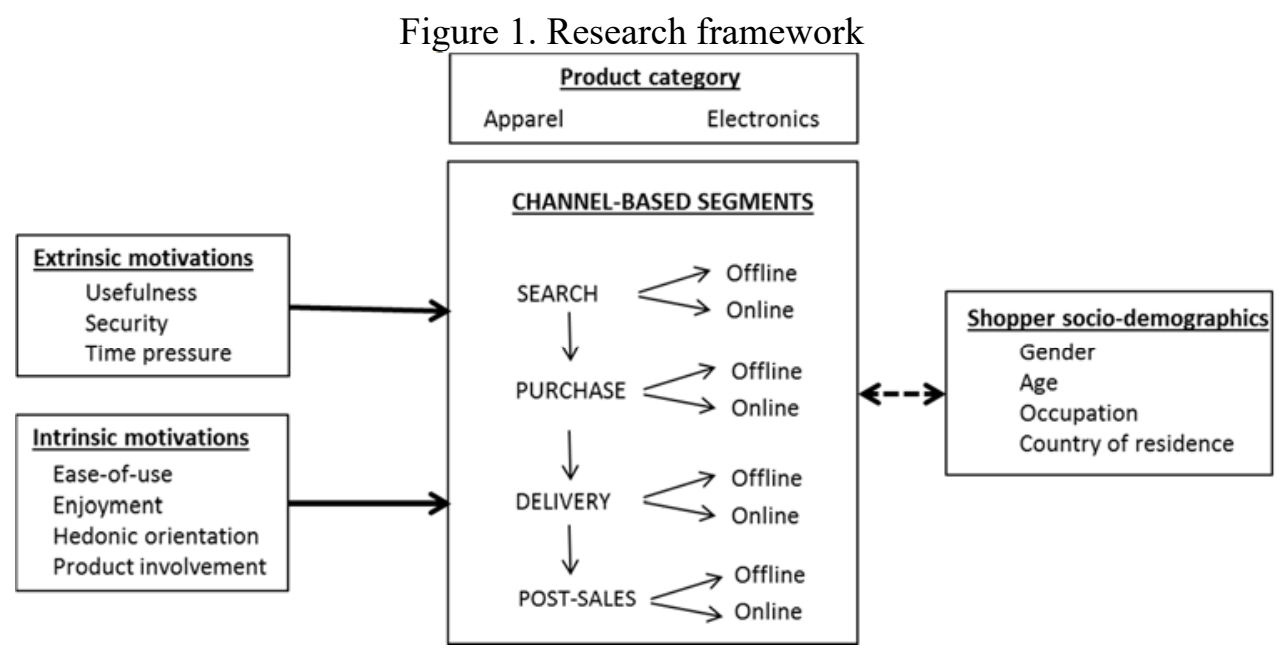

Notwithstanding the expectation that channel choice is driven by different variables at different shopping stages, we believe that the choice of channel at a stage of shopping is dependent of the choice of channel at the previous or following stages. We can identify channel lock-in when the shopper stays in a single channel during the shopping process and crosschannel synergies if the shopper changes channel to complete the process. The efficiency of the 
online channel for finding information before making a purchase explains why the most common multichannel pattern is to search online and purchase offline. This is the researchshopper phenomenon, defined by Verhoef et al. (2007) as the tendency of consumers to use one channel for search and another one for purchase. The findings of their study point out the lack of lock-in power of the Internet channel, as it is not able to convert searchers into buyers, therefore, showing the cross-channel synergy between using the Internet for searching and the store for purchasing. Research on multichannel segmentation has found that there is a segment of consumers that uses mostly one channel to perform all shopping activities (e.g. the storefocused segment of Konuş et al. 2008 or Thomas and Sullivan, 2005 and the online segment of Schröder and Zaharia, 2008), and a segment that relies on different channels at different stages of shopping process (e.g. the migration segment of Knox, 2005, or the multichannel segment of Konuş et al. 2008 or Kushwaha and Shankar, 2007). Moreover, channel choice for search and purchase has been shown to be driven by different variables in the studies of Verhoef et al. (2007) and Schröder and Zaharia (2008), but Konuş et al. (2008) found similar channel choice patterns for the two shopping stages. Hence, we expect to find segments of shoppers that use channels differently across the shopping process and have different motivations to do so.

Our research framework suggests that channel based-segments will have different sociodemographic profiles regarding gender, age, occupation and country of residence. Herrero Crespo and Rodríguez del Bosque (2010) found that gender and education affect the importance of antecedents of channel choice for electronics, but age and occupation were not so relevant. Venkatesan et al. (2007) found that gender affects the adoption of multiple channels, with male customers being more likely to adopt a new channel. Kushwaha and Shankar (2013) found that multichannel shoppers were younger than offline customers and online-only customers were younger than multichannel shoppers. Contrary to most research evidences, Konuş et al (2008) did not find significant differences between channel-based segment regarding demographics. Bradinarayanan et al. (2012) found that culture affects multichannel behaviour.

We also argue that product category influences the use of channels for shopping. Peterson et al. (1997) stressed the need to explicitly include product characteristics when evaluating the impact of the Internet for searching and purchasing. When considering the stages of multichannel shopping, researchers have noted that the utility of one channel for a specific stage depends on the product category (Alba et al., 1997; Balasubramanian et al. 2005). Transaction costs economics again grounds our expectation that channel usage differs by product category. The study of Liang and Huang (1998) analysed, among other categories, shoes and microwave ovens, and found that the transaction costs at each stage of shopping were different by product. Teo and $\mathrm{Yu}$ (2005) found that the difficulty of physically assessing product quality affects online buying intentions. Products can be classified according to the extent to which consumers can research their characteristics before purchasing (Nelson, 1970; Chocarro et al., 2013). Goods for which such an investigation is economically feasible are termed search goods, while experience goods are those for which this research is not economically feasible. For experience goods such as clothing, the traditional offline channel may be preferred for purchasing as the qualities of the product can be fully appreciated and risk can be reduced, whereas for search goods such as electronics, whose features can be evaluated objectively, the online channel may be more efficient to search and compare alternatives and make the purchase decision.

\subsection{Drivers of differentiated multichannel behaviours}

Our framework considers two main types of motivations following the classification of extrinsic and intrinsic motivations as the drivers of channel usage across the shopping process (Vallerand, 1997; Deci and Ryan, 1987). Extrinsic motivations will explain that the shopper uses the online channel because he/she achieves rewards as a result of using it, i.e. the performance of the shopping task, whereas intrinsic motivations will explain the use of the 
online channel because the shopper achieves rewards in the process of using it, i.e. a free of effort task.

\subsubsection{Extrinsic motivations}

TAM captures extrinsic motivation by the perceived usefulness construct, as it contributes to the instrumentality of the channel and enhances the performance of the shopping task (Davis, 1989; Venkatesh, 2000). We define perceived usefulness as the belief that the online channel improves the efficiency of the shopping process. Perceived usefulness has often been included in models to explain attitudes or intentions to purchase from online channels, with most of the studies showing a positive relationship. (Childers et al., 2001; Ha and Stoel, 2009). During the search stage, the online channel becomes particularly useful as it allows easy comparison and evaluation of alternatives, thus lowering information search costs

(Balasubramanian et al., 2005) and increasing the attractiveness of the channels (Verhoef at al., 2007). Most multichannel retailers are now allowing returns and order cancellations of online purchases at the physical stores (Chatterjee, 2010). When the shopper has to return an item bought online the decision whether to do it at a store or online will be affected by the perception of the usefulness of the online medium and the transaction costs involved (Liang et al., 1998). Post-sales activities include inquiring about the product or making a claiming about it and doing so online would require a high perception of channel usefulness as consumers may fear that their inquiries or service requests would not be handled efficiently online, thereby increasing transaction costs (Liang and Huang, 1998; Teo and Yu, 2005). Thus, we hypothesize:

H1a: A higher level of perceived usefulness is positively associated to the use of the online channel (vs. the offline channel) for search.

$\mathrm{H} 1 \mathrm{~b}$ : A higher level of perceived usefulness is positively associated to the use of the online channel (vs. the offline channel) for purchase.

H1c: A higher level of perceived usefulness is positively associated to the use of the online channel (vs. the offline channel) for post-sales.

The perception of security one gets when using the channels may incline consumers to use one channel more than the other. Perceived security of the online channel refers to the belief that the Internet is a secure option for sending personal information. The total utility of a channel for shopping is affected by its perceived security (Alba et al., 1997) and this factor acts as an extrinsic motivation for the shopper who gets a security payoff when using a channel perceived as more secure. Many consumers search online but refrain from purchasing online as they are afraid of sending credit card and personal data over the Internet, thus the use of the Internet for purchasing will be higher when the perception of security rises. There is some evidence of this relationship (Salisbury et al., 2001; Cha, 2011), but Montoya-Weiss et al. (2003) did not reach conclusive findings and suggested that perceived security may be relevant to the online channel depending on the context. Perceived security is expected to affect channel choice for purchase and product returns where money and personal data are involved, but as Verhoef et al. (2007) found, it is not expected to affect channel attractiveness for searching, as using the Internet for searching does not usually require disclosing personal or financial data. Hence:

H2a: A higher level of perceived security is not significantly associated to the use of the online channel (vs. the offline channel) for search.

$\mathrm{H} 2 \mathrm{~b}$ : A higher level of perceived security is positively associated to the use of the online channel (vs. the offline channel) for purchase.

H2c: A higher level of perceived security is positively associated to the use of the online channel (vs. the offline channel) for post-sales.

Time pressure, defined as the consideration by the consumer of time as a scarce and valuable resource, may have an effect on channel choice for all the phases of the shopping process. Generally, time-pressed consumers will spend less time searching and will seek convenient ways to purchase and return (if needed) the products, thus time pressure acts as an 
extrinsic motivation as it relates to the desire to accomplish the shopping task fast. Staying in a single channel can be a way of saving time, for that reason, Konuş et al. (2008) predicted that consumers pressed for time would be less likely to shop in multiple channels across the stages of the shopping process. However, they did not find a significant effect for this relationship. Previous research reveals that consumers, specially "hurried consumers", perceive online shopping to be a time saving practice (Alreck and Settle 2002). In the context of multichannel retailing, Chocarro et al. (2013) conclude that consumers are more likely to select the online channel for purchasing when they are pressed for time. We believe that performing after-sales activities online is not a good option for time-pressed shoppers as it would involve a delay in the answer (product exchanged/repaired, query solved) that is avoided when going to the store where the outcome is normally immediate. Notwithstanding, according to qualitative research conducted by Alreck et al. (2009), consumers only rarely report using the Internet to save time, the majority of respondents argue that the rapid delivery options for product returns are overpriced and the regular delivery is too slow. In fact, Chatterjee (2010) found that consumers with high waiting time costs tend to complete the purchase process offline. Thus:

H3a: A higher shopper time pressure is positively associated to the use of the online channel (vs. the offline channel) for search.

$\mathrm{H} 3 \mathrm{~b}$ : A higher shopper time pressure is negatively associated to the use of the online channel (vs. the offline channel) for purchase.

H3c: A higher shopper time pressure is negatively associated to the use of the online channel (vs. the offline channel) for post-sales.

\subsubsection{Intrinsic motivations}

TAM captures intrinsic motivation by the perceived ease-of-use construct (Davies, 1989; Venkatesh, 2000; Van der Heijden, 2004). In contrast to usefulness, which relates to the outcomes of the process, perceived ease-of-use relates to the effort that needs to be put into the shopping process. Perceived ease-of-use of the online channel is defined as the degree to which the consumer believes using the Internet for shopping will require little effort. Although consumers have learned to navigate the websites of companies, Rose et al. (2012) conclude that ease-of-use of the online store continues to be an important factor in influencing consumer attitude and behaviour for purchasing online. Verhoef at al. (2007) found that attributes related to ease-of-use influence the attractiveness of the channels used for searching. Post-sales activities are quite recent in the online context and are undertaken by shoppers less frequently than searching and purchasing. Post-sales activities have traditionally involved bi-directional personal communication with staff and conducting these communications online will increase bargaining transaction costs if the perceived ease-of-use of the Internet is low (Teo and $\mathrm{Yu}$, 2005). Hence:

H4a: A higher level of perceived ease-of-use is positively associated to the use of the online channel (vs. the offline channel) for search.

H4b: A higher level of perceived ease-of-use is positively associated to the use of the online channel (vs. the offline channel) for purchase.

H4c: A higher level of perceived ease-of-use is positively associated to the use of the online channel (vs. the offline channel) for post-sales.

The first papers that expanded the TAM model to incorporate intrinsic motivations included the perceived enjoyment construct (Teo et al., 1999; Venkatesh, 2000). Ignoring the hedonic aspect of using the Internet can be a major omission (Alba et al., 1997; Childers et al., 2001). Perceived enjoyment refers to the extent the consumer thinks using the online channel for shopping is fun and pleasant in itself. Previous research has observed that perceived enjoyment affects the attractiveness of the Internet for purchasing (Verhoef et al., 2007) and the attitudes towards the online channel (Childers et al., 2001; Ha and Stoel, 2009). There is limited insight into how enjoyment of the Internet affects channel use for searching, but we can expect, together with Verhoef et al. (2007), that channel use for search is explained by enjoyment of the Internet shopping experience. Doing product returns means following systematic procedures 
that one has to learn and become used to; we expect that shoppers who enjoy the Internet for shopping would be more inclined to learn about those procedures. Thus:

H5a: A higher level of perceived enjoyment is positively associated to the use of the online channel (vs. the offline channel) for search.

$\mathrm{H} 5 \mathrm{~b}$ : A higher level of perceived enjoyment is positively associated to the use of the online channel (vs. the offline channel) for purchase.

H5c: A higher level of perceived enjoyment is positively associated to the use of the online channel (vs. the offline channel) for post-sales.

Hedonic orientation or motivation refers to the enjoyment of shopping in itself as opposite to shopping as a task. Contrary to the perceived enjoyment variable, this is a motivation that does not refer specifically to enjoyment of the online medium, but to the pleasure encountered in the task of shopping. We believe that consumers that enjoy shopping will enjoy the shopping process over the Internet more than those with a low hedonic shopping orientation. Overby and Lee (2006) found that customers with higher hedonic motivations prefer the online retail channel for purchasing. On the contrary, To et al. (2007) concluded that a hedonic orientation would drive offline search and purchase. Konuş et al. (2008) analysed segments formed on the basis of attitudes towards channels for search and purchase and found that a hedonic orientation is related to the use of the channels, as the segment of multichannel shoppers are the ones with a higher hedonic orientation. Schröder and Zaharia (2008) found that customers who use store channels to seek information and purchase have a higher hedonic orientation than shoppers of online channels. We are inclined to believe that hedonic shoppers will prefer offline to online shops for searching and purchasing since those individuals do not value the higher convenience offered by the online channel but the increased opportunities for enjoyment offered by offline channels. Returning products at the store allows the customer to shop around for exchange alternatives and this behaviour is more likely in hedonic shoppers. Coming back to the store for exchanges provides an extra opportunity to interact with peers and staff, which are hedonic motivations (Tauber, 1972).

H6a: A higher shopper hedonic orientation is negatively associated to the use of the online channel (vs. the offline channel) for search.

H6b: A higher shopper hedonic orientation is negatively associated to the use of the online channel (vs. the offline channel) for purchase.

H6c: A higher shopper hedonic orientation is negatively associated to the use of the online channel (vs. the offline channel) for post-sales.

Consumer involvement with the product category is a relevant variable related to multichannel behaviour (Kumar and Venkatasan, 2005). Shoppers that are more involved in the product category will get rewarded from the process of shopping in itself. Highly involved consumers search and compare more information before making a purchase (Balabanis and Reynolds, 2001), so product involvement would affect the use of the channels. Peterson et al. (1997) and Balasubramanian et al. (2005) suggest that consumers with expertise in the product category are able to make decisions relying only on the factual information provided online. Wolfinbarger and Gilly (2001) explored the role of involvement with the product category as an experiential motivation to search and purchase online and found that online shoppers show higher levels of product involvement. In the apparel context, Jones and Kim (2010) obtained a strong positive association between clothing involvement and online apparel purchasing intention. Regarding after sales activities, highly involved consumers are more likely to return products as they can clearly distinguish a bad product choice (Maity and Arnold, 2013), and feel less uncertainty about undertaking post-sales activities online. In fact, as highly involved shoppers have made investments in knowledge of the product category the transaction costs involved in performing shopping activities online decreases (Teo and $\mathrm{Yu}, 2005$ ), making shoppers more likely to use the online channel. 
H7a: A higher product involvement is positively associated to the use of the online channel (vs. the offline channel) for search.

H7b: A higher product involvement is positively associated to the use of the online channel (vs. the offline channel) for purchase.

H7c: A higher product involvement is positively associated to the use of the online channel (vs. the offline channel) for post-sales.

\section{Methodology}

\subsection{Data source}

We designed an online survey aimed at British and Spanish multichannel retail customers. The survey was administered to two Internet panels, one in the UK and another in Spain. These two countries differ significantly in the overall penetration of B2C e-commerce The UK shows one of the highest penetration rates of online shopping in Europe while Spain, although having a lower penetration rate, is one of the countries where this figure is growing faster. In fact, 74\% of UK adults bought products or services online in 2014 (ONS, 2015), while $37 \%$ did in Spain (Ontsi, 2015). We selected shoppers within two product categories: apparel and electronics, as typical experience and search goods, respectively. These categories differ in terms of purchase frequency and complexity and retailers' branding and distribution strategies and should provide variation in the consumer perceptions of the channels. For the purpose of our study we defined multichannel shoppers as those using both the online and offline channels of a retailer during the shopping process, that is, a consumer who searches online and purchases offline would be a multichannel shopper. Panellists were screened to select those members that fit our definition of a multichannel shopper, with the criteria being that they had purchased (online or offline) within the category during the last year and had shopped online during the last year. Gender and age quotas were set for the sample to be representative of multichannel shoppers in each category and country. Data was collected in November 2013 and comprises 1,533 shoppers, being 49.6\% from Spain and 50.4\% from United Kingdom. Half of the interviews refer to the apparel product category and half to the electronics category. Regarding gender, $46.4 \%$ of respondents are male and $53.6 \%$ female for the total sample, with the percentages being different for the electronics and apparel samples according to the corresponding weight of each gender in the customer base of each retail activity. Similarly, all age groups are represented in the sample (i.e. $19.5 \%$ is $18-24$ years old, $26.4 \%$ is $25-34,22.9 \%$ is $35-44,17.2$ is $45-54$ and $14 \%$ is older than 54 ). The sample is highly representative of the distribution of online shoppers according to recent surveys ( $\mathrm{PwC}$ Global Online Shopping Habits, 2014; Webloyalty, 2014).

\subsection{Measurement and operationalization}

For each product category (i.e. apparel and consumer electronics) we measured channel choice patterns over the last year for each of the main stages of the shopping process, i.e. search, purchase, delivery and post-sales. Respondents were asked about the degree of usage of the online versus the offline channel on a five-point scale where $1=$ always over the Internet, and $5=$ always at the store ${ }^{2}$. The variables to capture consumer perceptions and motivations were based on scales employed in previous studies (see Appendix 1) and measured on five-point Likert scales.

Since our main objective was twofold: to assess if the drivers of channel usage are different at each shopping stage, and to characterize multichannel shoppers, we combined two methodologies. To identify the intrinsic and extrinsic variables influencing the usage of online channels across the purchase process, we estimated multiple linear regression models for each stage (i.e. information search, purchase and post-sales) for each product category: apparel and consumer electronics. Having obtained support for the power of those variables to affect

\footnotetext{
${ }^{2}$ These variables were reverted in subsequent analysis for an easier interpretation of results, so 1 means always offline and 5 always online.
} 
channel usage, the technique of cluster analysis was performed as a second step in order to obtain customer segments. In particular, we applied a two-step clustering method, first, we analysed data using Ward hierarchical clustering to decide on the number of clusters, and second, we applied the k-means procedure to obtain the profile of the segments. Three channel usage variables were considered as segmentation criteria: usage of the online versus the offline channel for searching, purchasing and post-sales. We did not use channel usage for delivery as it would have meant restricting the sample to those having purchased online and having the choice to have the product delivered at a local store or at home. This variable, together with the rest of variables, was used to characterize the obtained channel-based segments. We applied this clustering procedure for the two product categories. We performed ANOVA tests to identify the significant differences between the clusters. Finally, to characterise the segments on sociodemographics characteristics we produced contingency tables and performed chi-square tests.

\section{Findings}

The results produced by the multiple linear regression models are shown in Table 2 . The results are somewhat different for the two product categories considered and for the stages of shopping. In particular, different variables influence channel choice at each shopping stage.

For information search, usefulness and product involvement are key variables positively influencing Internet usage for both apparel and electronics shoppers, while hedonic orientation is positively related to the use of offline channels. For the purchase stage, usefulness and product involvement are again relevant to explain online channel usage for both product categories, while enjoyment of the Internet and hedonic shopping orientation are drivers only for apparel. Security emerges as a statistically significant factor for both product categories, although its impact on Internet usage is stronger for electronics. For the product returns stage, product involvement is positively related to Internet usage for both apparel and electronics. Enjoyment and hedonic orientation influence Internet usage for apparel, and security for electronics. Thus, as can be seen in Table 2, all the variables included in our research framework are significant to explain a differentiated use of the channels, although some are relevant only at one stage or for one product category.

Thus, regarding the extrinsic motivations, the significant influence of perceived usefulness of the Internet for information search and purchase for both apparel and electronics consumers support $\mathrm{H} 1 \mathrm{a}$ and $\mathrm{H} 1 \mathrm{~b}$ respectively, but not $\mathrm{H} 1 \mathrm{c}$ as the influence of usefulness on online channel usage for post-sales is not significant. Security influences all stages of shopping for electronics but not for apparel, thus H2a that stated no influence is supported for apparel, and $\mathrm{H} 2 \mathrm{~b}$ and $\mathrm{H} 2 \mathrm{c}$ are supported only for electronics. This can be explained by the fact that buying electronics tends to be a more rational and onerous task than buying apparel, and thus the shopper is more conscious of the risks involved. We do not find support for Hypotheses 3 as time pressure is not a significant driver of the usage of the channels, implying that the online channel is not perceived a time-saving option. For the intrinsic variables, Hypotheses 4 is not supported as there is no significant effect of ease-of-use at any stage of shopping. Perceived enjoyment of the Internet drives online channel usage for all stages of shopping but only for apparel, obtaining partial support for Hypotheses 5, which is related to more hedonic nature of apparel shopping. Hypothesis 6a stated the link between lower hedonic orientation and online search, this is supported for both categories; H6b and H6c, on the relationship of hedonic orientation with purchase and post-sales are supported only in the case of apparel. Finally, product involvement emerges as a strong driver of online channel usage for all the stages of shopping and for both product categories, in line with Hypotheses 7. 
Table 2. Multiple linear regression for online versus offline channel usage at different stages of the purchase process

\begin{tabular}{|c|c|c|c|c|c|c|c|c|c|}
\hline APPAREL & \multicolumn{3}{|c|}{ Information search } & \multicolumn{3}{|c|}{ Purchase } & \multicolumn{3}{|c|}{ Post-sales } \\
\hline Independent variables & $\begin{array}{l}\text { Non-stand. } \\
\text { coeff. }\end{array}$ & $\begin{array}{l}\text { Stand. } \\
\text { coeff. }\end{array}$ & $t$ & $\begin{array}{c}\text { Non-stand. } \\
\text { coeff. }\end{array}$ & Stand. coeff. & $t$ & $\begin{array}{c}\text { Non-stand. } \\
\text { coeff. }\end{array}$ & $\begin{array}{l}\text { Stand. } \\
\text { coeff. }\end{array}$ & $t$ \\
\hline Constant & 2.399 & - & $8.98^{\mathrm{a}}$ & 0.420 & - & 1.36 & 0.004 & - & 0.01 \\
\hline $\begin{array}{l}\text { Extrinsic motivations } \\
\text { - Usefulness } \\
\text { - Security } \\
\text { - Time pressure } \\
\end{array}$ & $\begin{array}{c}0.204 \\
-0.009 \\
-0.021\end{array}$ & $\begin{array}{c}0.154 \\
-0.008 \\
-0.020\end{array}$ & $\begin{array}{l}3.29^{\mathrm{a}} \\
-0.22 \\
-0.61\end{array}$ & $\begin{array}{c}0.146 \\
0.095 \\
-0.022\end{array}$ & $\begin{array}{c}0.096 \\
0.070 \\
-0.019\end{array}$ & $\begin{array}{c}2.03^{\mathrm{b}} \\
1.88^{\mathrm{c}} \\
-0.56\end{array}$ & $\begin{array}{c}-0.007 \\
0.122 \\
-0.105\end{array}$ & $\begin{array}{c}-0.004 \\
0.073 \\
-0.069\end{array}$ & $\begin{array}{c}-0.07 \\
1.59 \\
-1.66^{\mathrm{c}} \\
\end{array}$ \\
\hline $\begin{array}{l}\text { Intrinsic motivations } \\
\text { - Ease-of-use } \\
\text { - Enjoyment } \\
\text { - Hedonic orientation } \\
\text { - Product involvement }\end{array}$ & $\begin{array}{c}-0.037 \\
0.203 \\
-0.202 \\
0.154\end{array}$ & $\begin{array}{c}-0.029 \\
0.164 \\
-0.170 \\
0.131\end{array}$ & $\begin{array}{c}-0.65 \\
3.50^{\mathrm{a}} \\
-4.48^{\mathrm{a}} \\
3.63^{\mathrm{a}}\end{array}$ & $\begin{array}{c}0.063 \\
0.211 \\
-0.196 \\
0.315\end{array}$ & $\begin{array}{c}0.043 \\
0.149 \\
-0.145 \\
0.233\end{array}$ & $\begin{array}{c}0.95 \\
3.13^{\mathrm{a}} \\
-3.76^{\mathrm{a}} \\
6.39^{\mathrm{a}}\end{array}$ & $\begin{array}{c}0.098 \\
0.230 \\
-0.168 \\
0.294\end{array}$ & $\begin{array}{c}0.055 \\
0.133 \\
-0.099 \\
0.171\end{array}$ & $\begin{array}{r}0.97 \\
2.28^{\mathrm{b}} \\
-2.13^{\mathrm{b}} \\
3.91^{\mathrm{a}}\end{array}$ \\
\hline $\begin{array}{l}\text { Socio-demographic variables } \\
\text { - Gender (reference: Female) } \\
\text { - Age } \\
\text { - Country (reference: Spain) }\end{array}$ & $\begin{array}{c}0.031 \\
-0.007 \\
0.734\end{array}$ & $\begin{array}{c}0.015 \\
-0.084 \\
0.371\end{array}$ & $\begin{array}{c}0.45 \\
-2.64^{\mathrm{a}} \\
11.19^{\mathrm{a}}\end{array}$ & $\begin{array}{c}0.240 \\
-0.003 \\
0.631\end{array}$ & $\begin{array}{c}0.100 \\
-0.027 \\
0.278\end{array}$ & $\begin{array}{l}3.02^{\mathrm{a}} \\
-0.84 \\
8.29^{\mathrm{a}}\end{array}$ & $\begin{array}{l}0.209 \\
0.013 \\
0.795\end{array}$ & $\begin{array}{l}0.070 \\
0.102 \\
0.280\end{array}$ & $\begin{array}{l}1.75^{\mathrm{c}} \\
2.60^{\mathrm{a}} \\
6.83^{\mathrm{a}} \\
\end{array}$ \\
\hline Adjusted $\mathbf{R}^{2}$ & \multicolumn{3}{|c|}{$0.263^{\mathrm{a}}$} & \multicolumn{3}{|c|}{$0.243^{\mathrm{a}}$} & \multicolumn{3}{|c|}{$0.183^{\mathrm{a}}$} \\
\hline ELECTRONICS & \multicolumn{3}{|c|}{ Information search } & \multicolumn{3}{|c|}{ Purchase } & \multicolumn{3}{|c|}{ Post-sales } \\
\hline Independent variables & $\begin{array}{l}\text { Non-stand. } \\
\text { coeff. }\end{array}$ & $\begin{array}{l}\text { Stand. } \\
\text { coeff. }\end{array}$ & $t$ & $\begin{array}{c}\text { Non-stand. } \\
\text { coeff. }\end{array}$ & Stand. coeff. & $t$ & $\begin{array}{c}\text { Non-stand. } \\
\text { coeff. }\end{array}$ & $\begin{array}{l}\text { Stand. } \\
\text { coeff. }\end{array}$ & $t$ \\
\hline Constant & 3.149 & - & $13.78^{\mathrm{a}}$ & 0.471 & - & 1.32 & -0.088 & - & -0.16 \\
\hline $\begin{array}{l}\text { Extrinsic motivations } \\
\text { - Usefulness } \\
\text { - Security } \\
\text { - Time pressure } \\
\end{array}$ & $\begin{array}{c}0.201 \\
0.123 \\
-0.040 \\
\end{array}$ & $\begin{array}{c}0.196 \\
0.128 \\
-0.048\end{array}$ & $\begin{array}{l}3.93^{\mathrm{a}} \\
3.30^{\mathrm{a}} \\
-1.35\end{array}$ & $\begin{array}{c}0.175 \\
0.310 \\
-0.054 \\
\end{array}$ & $\begin{array}{l}0.107 \\
0.202 \\
0.041 \\
\end{array}$ & $\begin{array}{l}2.21^{\mathrm{b}} \\
5.35^{\mathrm{a}} \\
-1.17\end{array}$ & $\begin{array}{c}-0.085 \\
0.496 \\
0.048\end{array}$ & $\begin{array}{c}-0.045 \\
0.281 \\
0.029\end{array}$ & $\begin{array}{c}-0.64 \\
5.26^{\mathrm{a}} \\
0.60 \\
\end{array}$ \\
\hline $\begin{array}{l}\text { Intrinsic motivations } \\
\text { - Ease-of-use } \\
\text { - Enjoyment } \\
\text { - Hedonic orientation } \\
\text { - Product involvement }\end{array}$ & $\begin{array}{c}0.050 \\
-0.028 \\
-0.119 \\
0.126\end{array}$ & $\begin{array}{c}0.047 \\
-0.028 \\
-0.114 \\
0.132 \\
\end{array}$ & $\begin{array}{c}1.04 \\
-0.56 \\
-2.73^{\mathrm{a}} \\
3.18^{\mathrm{a}} \\
\end{array}$ & $\begin{array}{c}0.037 \\
-0.025 \\
-0.081 \\
0.259\end{array}$ & $\begin{array}{c}0.021 \\
-0.015 \\
-0.048 \\
0.169\end{array}$ & $\begin{array}{r}0.49 \\
-0.32 \\
-1.19 \\
4.19^{\mathrm{a}}\end{array}$ & $\begin{array}{c}-0.192 \\
0.136 \\
-0.146 \\
0.351 \\
\end{array}$ & $\begin{array}{c}-0.099 \\
0.074 \\
-0.076 \\
0.186\end{array}$ & $\begin{array}{r}-1.60 \\
1.07 \\
-1.35 \\
3.38^{\mathrm{a}} \\
\end{array}$ \\
\hline $\begin{array}{l}\text { Socio-demographic variables } \\
\text { - Gender (reference: Female) } \\
\text { - Age } \\
\text { - Country (reference: Spain) }\end{array}$ & $\begin{array}{c}0.014 \\
-0.007 \\
0.158\end{array}$ & $\begin{array}{c}0.009 \\
-0.122 \\
0.101\end{array}$ & $\begin{array}{c}0.23 \\
-3.42^{\mathrm{a}} \\
2.85^{\mathrm{a}}\end{array}$ & $\begin{array}{l}0.095 \\
0.006 \\
0.551\end{array}$ & $\begin{array}{l}0.037 \\
0.060 \\
0.221\end{array}$ & $\begin{array}{l}1.06 \\
1.73^{\mathrm{c}} \\
6.37^{\mathrm{a}}\end{array}$ & $\begin{array}{l}0.136 \\
0.018 \\
0.734\end{array}$ & $\begin{array}{l}0.044 \\
0.157 \\
0.244\end{array}$ & $\begin{array}{c}0.92 \\
3.34^{\mathrm{a}} \\
5.23^{\mathrm{a}}\end{array}$ \\
\hline Adjusted R $\mathbf{R}^{2}$ & \multicolumn{3}{|c|}{$\frac{10.101}{0.127^{\mathrm{a}}}$} & \multicolumn{3}{|c|}{$0.170^{\mathrm{a}}$} & \multicolumn{3}{|c|}{$0.192^{\mathrm{a}}$} \\
\hline
\end{tabular}


Next, we analysed the behavioural patterns in channel usage across the shopping process. The Ward clustering algorithm produced segmentation trees that suggested the number of clusters should be five for both product categories ${ }^{3}$; we then performed $\mathrm{k}$-means clustering to obtain the final segments (see Table 3). Among the five final segments obtained for both apparel and electronics we find: one segment that uses the Internet more intensively than the rest of consumers at the different stages of the purchase process, a segment of offline shoppers, and three segments of cross-channel customers. Although we obtained the same number of segments and quite consistent profiles, there are differences in multichannel usage between categories. Online channels are used more at every stage for the product category of electronics, and particularly for information search. In both product categories we can observe that some of the consumers that use the online channel for searching move to the offline channel for purchasing. We can also observe that even when people shop online and have the product delivered at home, they tend to go to the store for product returns.

In order to characterize the segments, we look at the significant differences reported in Table 3. There are significant differences between the segments for all extrinsic variables except time-pressure in the case of electronics, and for all intrinsic variables except hedonic orientation in the case of both apparel and electronics. Table 3 also shows the socio-demographic profile of the segments. Country of residence shows a significant and consistent association with channel usage for both product categories. Segments showing an intense use of online channels have a significantly higher participation of British consumers, while segments characterized by the use of offline channels include a high percentage of Spanish consumers. Gender and professional status show significant differences only for the case of apparel and age only for the case of electronics.

Regarding segment interpretation and labelling, as mentioned, the characteristics of the segments are slightly different between the two categories as we discuss next. In the case of apparel, the segment of "online shoppers", the one using almost always the online channel for every stage of shopping, is integrated by a high proportion (69.2\%) of British consumers and male shoppers (42.7\%, the highest value among the clusters). Segment 2 comes after Segment 1 in the use of the online channel for purchasing. Even if consumers in this segment use online channels to a lesser degree than Segment 1, they show the highest scores of all segments in perceived usefulness, enjoyment and are the more time-pressed. We have called this segment "reluctant multichannel shoppers". It contains the highest proportion of women and the least amount of people over 45. Segment 3 has been named "uninvolved multichannel shoppers," since those included in this segment show weak intrinsic motivations to shop online, with the lowest enjoyment, hedonic orientation and product involvement levels. They search nearly always online but purchase nearly always at the store, possibly due the low perception of online security. Segment 4 has been called "true multichannel shoppers" as shoppers in this segment exhibit a well-balanced use of the offline and online channels; they have medium values in all the shopping motivations, except that they are the least time-pressed. They seem to enjoy shopping both online and offline. Segment 5, "offline shoppers," shows the lowest perceptions of usefulness and ease-of-use, which is evident in that they are the ones that use the online channel less, even for searching. They are mainly from Spain (82.1\%) and are composed of women $(61.5 \%)$, with high proportions being students and the unemployed.

Analysing the segments of multichannel shoppers for electronics, Segment 1, "online shoppers" shows a similar profile as in the apparel category. They show a high level of most

\footnotetext{
3 Five clusters is a parsimonious solution that ensures a low error sum of squares and significantly differentiated and usable segments from a marketing perspective for both samples. In particular, for the apparel sample, the error sum of squares within clusters drops dramatically from 2 to 5 clusters $(1498.24,1103.86,914.89$, and 797.75 for 2, 3, 4 and 5 clusters respectively) but from 5 to 6 clusters the fall is 709.92, and the number of elements in two of the 6 clusters is lower than 50 (less than 10\% of the sample), thus raising concerns about the ANOVA analysis. Similar results are obtained for the electronics sample: error sum of squares within clusters is $861.66,665.16,576.43$, and 503.02 for 2, 3, 4 and 5 clusters respectively, while it is 437.64 for 6 clusters. Three of the 6 resulting clusters encompass 42 elements or less (i.e. less than 10\%).Additionally, in order to validate the 5-cluster solution, a discriminant analysis is performed, resulting in $100 \%$ and $97.80 \%$ correctly classified cases for apparel and electronics, respectively.
} 
shopping motivations. This segment contains the highest proportion of British consumers $(61 \%)$ and is quite young (48.6\% under 35). Similarly to apparel, Segment 2 is a group that we have named "reluctant multichannel shoppers", as despite showing the highest scores for usefulness and ease-of-use, they do not use the online channels as often as the "online shoppers," particularly for purchasing and post-sales. They are a very young segment (40.9\% are 18-24 years old). Segment 3 has been called "online searchers." Consumers in this multichannel segment search information almost always online, but they tend buy offline. This may be explained by a low perceived security and by the cultural context ( $80.6 \%$ from Spain). Segment 4 is similar to the so called "true multichannel shoppers" for apparel as it shows the more balanced use of channels among the segments. They perceive the benefits of the online channel, but they do not abandon the offline channel. In the last segment, "offline shoppers" we find the lowest scores for all shopping motivations, which did not happen for apparel. Most of these shoppers come from Spain (82.4\%) and are older than 45 (55.9\%). 
Table 3. Characterization of multichannel segments. Apparel and electronics

\begin{tabular}{|c|c|c|c|c|c|c|c|c|c|c|c|c|}
\hline & $\begin{array}{l}\text { Seg.1 } \\
\text { Online } \\
\text { shoppers }\end{array}$ & $\begin{array}{c}\text { Seg.2 } \\
\text { Reluctant } \\
M C \\
\text { shoppers }\end{array}$ & $\begin{array}{c}\text { Seg.3 } \\
\text { Uninvolved } \\
\text { MC } \\
\text { shoppers }\end{array}$ & $\begin{array}{l}\text { Seg.4 } \\
\text { True MC } \\
\text { shoppers }\end{array}$ & $\begin{array}{l}\text { Seg.5 } \\
\text { Offline } \\
\text { shoppers }\end{array}$ & $\mathbf{F}$ & $\begin{array}{l}\text { Seg.1 } \\
\text { Online } \\
\text { shoppers }\end{array}$ & $\begin{array}{c}\text { Seg.2 } \\
\text { Reluctan } \\
t M C \\
\text { shoppers }\end{array}$ & $\begin{array}{c}\text { Seg.3 } \\
\text { Online } \\
\text { searcher } \\
\quad s\end{array}$ & $\begin{array}{c}\text { Seg.4 } \\
\text { True } \\
M C \\
\text { shoppers }\end{array}$ & $\begin{array}{l}\text { Seg.5 } \\
\text { Offline } \\
\text { shoppers }\end{array}$ & $\mathbf{F}$ \\
\hline On- vs. offline information search & 4.43 & 4.24 & 4.29 & 3.46 & 2.50 & $298.7^{\mathrm{a}}$ & 4.74 & 4.26 & 4.31 & 3.96 & 2.71 & $104.3^{\mathrm{a}}$ \\
\hline On- vs. offline purchase & 4.25 & 3.71 & 1.73 & 2.88 & 1.93 & $465.8^{\mathrm{a}}$ & 4.51 & 3.58 & 1.63 & 3.50 & 1.65 & $349.7^{\mathrm{a}}$ \\
\hline On- vs. offline post-sales & 4.11 & 1.55 & 1.37 & 3.56 & 1.32 & $509.6^{\mathrm{a}}$ & 4.71 & 1.53 & 1.25 & 3.60 & 1.53 & $599.0^{\mathrm{a}}$ \\
\hline $\begin{array}{l}\text { On- vs. offline delivery } \\
\text { Extrinsic motivations }\end{array}$ & 4.41 & 3.67 & 3.56 & 3.90 & 3.28 & $19.1^{\mathrm{a}}$ & 4.63 & 3.80 & 3.26 & 4.19 & 3.73 & $17.3^{\mathrm{a}}$ \\
\hline Usefulness & 4.19 & 4.28 & 3.95 & 3.86 & 3.67 & $13.9^{\mathrm{a}}$ & 4.08 & 4.16 & 3.84 & 4.00 & 3.49 & $5.2^{\mathrm{a}}$ \\
\hline Security & 3.78 & 3.66 & 3.34 & 3.61 & 3.44 & $4.9^{\mathrm{a}}$ & 3.97 & 3.83 & 3.09 & 3.70 & 2.96 & $21.4^{\mathrm{a}}$ \\
\hline $\begin{array}{l}\text { Time pressure } \\
\text { Intrinsic motivations }\end{array}$ & 3.59 & 3.79 & 3.56 & 3.37 & 3.65 & $2.3^{\mathrm{c}}$ & 3.47 & 3.53 & 3.53 & 3.54 & 3.41 & 0.2 \\
\hline Ease-of-use & 4.20 & 4.16 & 3.82 & 3.84 & 3.47 & $7.9^{\mathrm{a}}$ & 4.13 & 4.17 & 3.85 & 4.04 & 3.79 & $2.8^{\mathrm{b}}$ \\
\hline Enjoyment & 4.10 & 4.16 & 3.68 & 4.00 & 3.77 & $17.3^{\mathrm{a}}$ & 3.94 & 3.85 & 3.56 & 3.89 & 3.50 & $3.9^{\mathrm{a}}$ \\
\hline Hedonic orientation & 3.82 & 3.71 & 3.57 & 3.76 & 3.71 & 1.1 & 3.83 & 3.70 & 3.72 & 3.83 & 3.62 & 0.9 \\
\hline Product involvement & 3.30 & 3.11 & 2.80 & 3.20 & 2.89 & $7.4^{\mathrm{a}}$ & 3.51 & 3.33 & 3.07 & 3.48 & 2.84 & $8.1^{\mathrm{a}}$ \\
\hline Socio-demographic variables (\%) & & & & & & Chi2 & & & & & & Chi2 \\
\hline $\begin{array}{l}\text { Gender } \\
\text { - male } \\
\text { - female }\end{array}$ & $\begin{array}{l}42.7 \\
57.3 \\
\end{array}$ & $\begin{array}{l}22.7 \\
77.3\end{array}$ & $\begin{array}{l}27.4 \\
72.6 \\
\end{array}$ & $\begin{array}{l}30.6 \\
69.4 \\
\end{array}$ & $\begin{array}{l}38.5 \\
61.5\end{array}$ & $11.4^{\mathrm{b}}$ & $\begin{array}{r}68.6 \\
31.4 \\
\end{array}$ & $\begin{array}{l}57.6 \\
42.4\end{array}$ & $\begin{array}{l}58.2 \\
41.8\end{array}$ & $\begin{array}{l}62.0 \\
38.0\end{array}$ & $\begin{array}{l}55.9 \\
44.1\end{array}$ & 3.4 \\
\hline $\begin{array}{l}\text { Age } \\
-18-24 \\
-25-34 \\
-35-44 \\
-45-54 \\
- \text { over } 55\end{array}$ & $\begin{array}{c}14.7 \\
36.4 \\
28.0 \\
16.1 \\
4.8 \\
\end{array}$ & $\begin{array}{c}21.2 \\
37.9 \\
33.3 \\
3.1 \\
4.5 \\
\end{array}$ & $\begin{array}{c}29.0 \\
25.8 \\
22.6 \\
16.1 \\
6.5 \\
\end{array}$ & $\begin{array}{c}17.3 \\
38.8 \\
22.4 \\
17.3 \\
4.2 \\
\end{array}$ & $\begin{array}{c}21.8 \\
27.9 \\
26.3 \\
15.6 \\
8.4 \\
\end{array}$ & 21.6 & $\begin{array}{l}19.1 \\
29.5 \\
20.0 \\
20.0 \\
11.4 \\
\end{array}$ & $\begin{array}{c}40.9 \\
21.2 \\
16.7 \\
15.2 \\
6.0 \\
\end{array}$ & $\begin{array}{c}32.8 \\
20.9 \\
25.4 \\
9.0 \\
11.9 \\
\end{array}$ & $\begin{array}{l}24.8 \\
27.9 \\
23.3 \\
14.0 \\
10.0 \\
\end{array}$ & $\begin{array}{l}11.8 \\
14.7 \\
17.6 \\
20.6 \\
35.3 \\
\end{array}$ & $38.1^{\mathrm{a}}$ \\
\hline $\begin{array}{l}\text { Country } \\
\text { - Spain } \\
\text { - United Kingdom }\end{array}$ & $\begin{array}{l}30.8 \\
69.2\end{array}$ & $\begin{array}{l}45.5 \\
54.5\end{array}$ & $\begin{array}{l}51.6 \\
48.4\end{array}$ & $\begin{array}{l}42.9 \\
57.1\end{array}$ & $\begin{array}{l}82.1 \\
17.9\end{array}$ & $95.0^{\mathrm{a}}$ & $\begin{array}{l}39.0 \\
61.0\end{array}$ & $\begin{array}{l}59.1 \\
40.9\end{array}$ & $\begin{array}{l}80.6 \\
19.6\end{array}$ & $\begin{array}{l}42.6 \\
57.4\end{array}$ & $\begin{array}{l}82.4 \\
17.6\end{array}$ & $46.9^{a}$ \\
\hline $\begin{array}{l}\text { Professional status } \\
\text { - employee } \\
\text { - employer } \\
\text { - student } \\
\text { - unemployed } \\
\text { - housewife } \\
\text { - pensioner }\end{array}$ & $\begin{array}{c}69.9 \\
7.0 \\
5.6 \\
6.3 \\
9.1 \\
2.1 \\
\end{array}$ & $\begin{array}{c}68.2 \\
1.5 \\
10.6 \\
6.1 \\
10.6 \\
3.0 \\
\end{array}$ & $\begin{array}{c}64.5 \\
4.8 \\
17.7 \\
8.2 \\
3.2 \\
1.6 \\
\end{array}$ & $\begin{array}{c}61.2 \\
8.2 \\
9.2 \\
11.2 \\
10.2 \\
0.0 \\
\end{array}$ & $\begin{array}{c}55.3 \\
8.4 \\
16.2 \\
13.4 \\
4.5 \\
2.2 \\
\end{array}$ & $31.6^{\mathrm{b}}$ & $\begin{array}{c}66.7 \\
10.5 \\
7.6 \\
9.5 \\
3.8 \\
1.9 \\
\end{array}$ & $\begin{array}{c}53.0 \\
10.6 \\
16.7 \\
12.1 \\
3.0 \\
4.5 \\
\end{array}$ & $\begin{array}{c}43.3 \\
10.4 \\
23.9 \\
13.4 \\
7.5 \\
1.5 \\
\end{array}$ & $\begin{array}{c}58.9 \\
11.6 \\
11.6 \\
9.3 \\
3.9 \\
4.7 \\
\end{array}$ & $\begin{array}{c}67.6 \\
2.9 \\
8.8 \\
11.8 \\
0.0 \\
8.8 \\
\end{array}$ & 25.7 \\
\hline$\%$ consumers & 26.1 & 12.0 & 11.3 & 17.9 & 32.7 & & 26.1 & 16.5 & 16.7 & 32.2 & 8.5 & \\
\hline
\end{tabular}




\section{Conclusions and managerial implications}

Our study contributes to the current literature on multichannel consumer behaviour in the three following ways. First, we demonstrate that channel choice is explained by different variables at each of the three phases of the purchase process considered (i.e. search, purchase and post-sales). This adds considerably to the literature, as channel choice for search has been seldom considered and channel choice for post-sales, to the best of our knowledge, has never been investigated. Second, we show that product category affects the usage of the online versus offline channels at each stage. Third, we provide a full characterization of channel-based segments that can serve a as guide to understand cross-channel behaviour and design channel migration campaigns.

Our research framework is based on an extension of the TAM model considering the motivational model to account for a variety of extrinsic and intrinsic motivations to explain channel usage, and on transaction costs economics to explain different channel usage at each shopping stage and for each product category. Our main conclusion is that the variables investigated influence channel usage differently at each purchase stage and for each product category. The only common variable explaining a higher use of online channels across the shopping process and for both product categories is product involvement: those shoppers more involved with the product category use the online channel more, possibly due to a higher shopping frequency and familiarity with the channel. Focusing on each specific stage there are more common variables in the two categories: for information search, product involvement and usefulness explain a higher use of online channels and hedonic orientation a lower use of online channels. For purchase, the common variables are again product involvement and usefulness and for post-sales only, product involvement appears in both product categories. The differences between categories point out that intrinsic motivations such as enjoyment of the Internet and hedonic orientation are more relevant when shopping for apparel than when shopping for electronics. Extrinsic motivations such as usefulness and security better explain channel usage in the case of electronics.

A second interesting conclusion of our research is that multichannel shoppers are not a homogeneous group and differentiated patterns of channel usage across the shopping process can be identified. Two polarised segments are identified: the online shopper and the offline shopper, and between them three segments of cross-channel shoppers. Although this finding is generally true for both product categories, there are some differences in the characteristics and the sizes of the segments, e.g. in the apparel category the offline segment is larger and one exclusive cross-channel segment appears in each category. Our conclusion regarding multichannel behaviour is that there are crosschannel synergies, as most shoppers use some combination of online and offline channels for searching, purchasing, delivery and product returns. In both product categories, we can confirm the trend of searching online and purchasing offline (webrooming), but we do not get strong support for the purchase online-collect at the store behaviour (click-and-collect) or search offline-purchase online (showrooming). In both product categories we identify a segment of true multichannel shoppers, which are those showing a balanced use of online and offline channel, possibly driven by intrinsic motivations towards shopping. We also find a common segment of shoppers, named "reluctant multichannel shoppers", as they value the most positively the attributes of the Internet but are not the ones shopping online more often. There might be other reasons driving the behaviour of online shoppers such as culture, habitat or deal proneness. At the other end, the segment shopping predominantly offline does show clear motivations to do so as it is the segment with lower perceptions of the usefulness and ease-of-use of the Internet in both product categories, and in the case of electronics, is the one with lower levels in all shopping motivations.

Our research findings have valuable implications for channel migration campaigns of multichannel retailers. If retailers want to persuade customers to search online they should continue improving the usefulness of their websites for finding the products, provide value-added information on the products and allow easy comparison of alternatives. Particularly, retailers must work on the perceived usefulness of their websites for searching as our results show that searching online is clearly 
driven by this extrinsic motivation. But if retailers want to encourage shoppers to visit both channels, they should work on efficient practices to make the search process swift and easy at the store and provide a more enjoyable shopping experience. Furthermore, our finding that the online channel loses some customers between the search and purchase stages indicates that retailers have to use additional incentives if they want to persuade shoppers to buy online. For instance, apparel retailers should promote the hedonic aspect of shopping online as perceived enjoyment and hedonic orientation are the drivers of online purchasing. This could be achieved by enhancing the sensory appeal of the website by showing the latest trends in complementary cues such as hairstyle or make-up or by including short videos showing the clothes in a context. For electronics retailers to encourage online purchasing it would be more important to increase the perceived usefulness and security of the website than to invest in making the shopping process more enjoyable. This could be achieved by providing full information about the products, reviews by other customers and expert advice or useful apps or tips for getting the maximum performance from electronic devices. Finally, if retailers wish to encourage shoppers to use the website for after-sales activities they should work, in the case of apparel retailers, on the perceptions of enjoyment and effectiveness, and in the case of electronics retailers, on perceived security. In any case, it is necessary to continue educating offline shoppers on the use and benefits of the online channel, and improving the layout, enjoyment and usability of the websites.

Finally, our findings imply that multichannel strategies cannot be mass marketing, as different segments choose channels to different degrees, for different reasons. Retailers should understand the types of customers they have, and the characteristics of these segments to better design and target them. If retailers wish to encourage cross-channel behaviour, they should work on channel integration to allow a smooth transition from one channel to another during the shopping process. Additionally, the fact that channel use for experience products and for search products significantly differs has implications for multi-category retailers. These retailers should differentiate their webpages for different product categories if they want to encourage the use of the online channel, as the shoppers of apparel demand different benefits from online shopping than the shoppers of electronics.

\section{Research limitations and further research}

Our paper has certain limitations stemming from the research design. Although using online panels is effective to reach multichannel shoppers, it might introduce some bias on the results because of different motivations of this population. Moreover, we measured channel usage as consumerreported past behaviour. It would be beneficial to use actual channel choice for a specific shopping occasion. This will also allow accounting for retailer-specific influences on consumer behaviour as the cross-channel options offered by specific retailers may explain cross-channel behaviour. As well, future research should take into account the sequential process of shopping by collecting longitudinal data that shows consumers' choice of channel for one stage given the choice taken at the previous stage.

Cross-channel behaviour also encompasses the use of mobile devices while being at the store to search or purchase, our research design has not considered this type of behaviour; however, this is an interesting research line to follow. The interaction between online and offline can take place when consumers go to the store to search, purchase, to collect items bought online or to return a product. We feel that more research is needed to investigate the delivery and after-sales stages of shopping in the multichannel context and the challenges and implications for retailers of driving online shoppers at the store for collection and product returns.

We have found different channel usage for two countries with different Internet penetration, but we have not tested if consumers who shop online are driven by the same variables irrespective of their nation; having a broader cross-cultural sample may help to refine our conclusions. Similarly, we have shown different channel behaviour for the two product categories considered; the inclusion of more product categories within the search and experience goods would be useful to validate our results. Moreover, within both product categories there are products that are bought for different 
reasons - e.g functional or fashion clothing, functional or leisure electronics. Lastly, our model could have missed important variables to explain channel choice. Future research could investigate the role of product characteristics (not only product category) on channel choice. As well, price of the product or deal proneness may possibly influence the use of different channels. Other lines of research point to the influence of the retailer's characteristics, such as brand value, assortment or coverage of the store network.

\section{Appendix 1. Measurement scales}

\begin{tabular}{|c|c|c|}
\hline Measures and items $\mathrm{a}^{\mathrm{a}}$ & Source & $\begin{array}{l}\text { Reliability } \\
(\text { Cronbach } \alpha)\end{array}$ \\
\hline $\begin{array}{l}\text { Usefulness } \\
\text { Shopping via the Internet allows me to shop faster } \\
\text { Shopping via the Internet makes me waste my time }{ }^{\mathrm{b}} \\
\text { Shopping via the Internet is useful for me } \\
\text { Shopping via the Internet makes my life easier }\end{array}$ & $\begin{array}{l}\text { Davis (1989) } \\
\text { Childers et al. } \\
(2001)\end{array}$ & 0.814 \\
\hline $\begin{array}{l}\text { Security } \\
\text { Using credit cards to make purchases over the Internet is safe } \\
\text { Making payments online is secure }\end{array}$ & Cha (2011) & 0.860 \\
\hline $\begin{array}{l}\text { Time pressure } \\
\text { I am always busy } \\
\text { I usually find myself pressed for time }\end{array}$ & $\begin{array}{l}\text { Konuş et al. } \\
(2008)\end{array}$ & 0.843 \\
\hline $\begin{array}{l}\text { Ease-of-use } \\
\text { Learning to shop over the Internet takes very long for me } \mathrm{e}^{\mathrm{b}} \\
\text { Internet shopping allows me to easily shop for what I want. } \\
\text { It is easy to become confident at Internet shopping }\end{array}$ & $\begin{array}{l}\text { Davis (1989) } \\
\text { Rose et al. } \\
(2012)\end{array}$ & 0.783 \\
\hline $\begin{array}{l}\text { Enjoyment } \\
\text { Shopping via the Internet is enjoyable } \\
\text { Shopping via the Internet is pleasant } \\
\text { Shopping via the Internet is boring }{ }^{\mathrm{b}} \\
\text { Shopping via the Internet is interesting }\end{array}$ & $\begin{array}{l}\text { Childers et al. } \\
(2001) \\
\text { Cha (2011) }\end{array}$ & 0.880 \\
\hline $\begin{array}{l}\text { Hedonic orientation } \\
\text { I like shopping for apparel and accessories/electronics } \\
\text { I take my time when I do shopping for apparel /electronics }\end{array}$ & $\begin{array}{l}\text { Konuş et al. } \\
(2008)\end{array}$ & 0.699 \\
\hline $\begin{array}{l}\text { Product involvement } \\
\text { How much time do you devote to apparel /electronics, relative to other } \\
\text { people? } \\
\text { How much are you involved with apparel /electronics? } \\
\text { How much do you feel like are you an apparel /electronics expert? } \\
\text { How intensively are you interested in apparel /electronics, relative to other } \\
\text { people? }\end{array}$ & $\begin{array}{l}\text { Kressman et al. } \\
(2006)\end{array}$ & 0.904 \\
\hline
\end{tabular}

${ }^{\text {a }}$ All items measured on a Likert scale where 1=Strongly disagree; 5=Strongly agree, except for Product involvement where $1=$ Much less than average; $5=$ Much more than average.

bItem deleted in scale purifying.

\section{References}

Alba, J., Lynch, J., Weitz, B., Janiszewski, C., Lutz, R., Sawyer, A., and Wood, S. (1997). Interactive home shopping: consumer, retailer, and manufacturer incentives to participate in electronic marketplaces. Journal of Marketing, 61 (July) 38-53.

Alreck, P. L. and R. B. Settle (2002). The hurried consumer: Time-saving perceptions of Internet and catalogue shopping. Journal of Database Marketing, 10(1):25.

Alreck, P.L., Dibartolo, G.R., Diriker, M., Dover, H.F., Passyn, K.A. and Settle, R.B. (2009). Time pressure, time saving and online shopping: Exploring a contradiction", Journal of Applied Business Research, Vol. 25 No. 5, pp. 85-91.

Ansari, A.; Mela, C., and Neslin, S. (2008). Customer Channel Migration. Journal of Marketing Research, 45 (1) $60-76$. 
Balabanis, G., and Reynolds, N. L. (2001). Consumer attitudes towards multi-channel retailers' Web sites: The role of involvement, brand attitude, Internet knowledge and visit duration. Journal of Business Strategies, 18(2), $105-131$

Balasubramanian, S., Raghunathan, R., and Mahajan, V. (2005). Consumers in a multichannel environment: Product utility, process utility, and channel choice. Journal of Interactive Marketing, 19(2), 12-30.

Badrinarayanan, V., Becerra, E. P., Kim, C. H., and Madhavaram, S. (2012). Transference and congruence effects on purchase intentions in online stores of multi-channel retailers: initial evidence from the US and South Korea. Journal of the Academy of Marketing Science, 40(4), 539-557.

Bellenger, D., Robertson, D. and Greenberg,B. (1977). Shopping centre patronage motives. Journal of Retailing, 53 (2), 29-38.

Bloch, P. H., Ridgway, N. M., and Dawson, S. A. (1994). The shopping mall as consumer habitat. Journal of retailing, 70(1), 23-42.

Brengman, M, Geuens, M., Weijters, B., Smith, S.M. and Swinyard, W.R. (2005). Segmenting Internet Shoppers Based on their Web-Usage-Related Lifestyle: A Cross-Cultural Validation. Journal of Business Research, 58 (1), 79-88.

Cavalieri, S., Gaiardelli, P., and Ierace, S. (2007). Aligning strategic profiles with operational metrics in aftersales service. International Journal of Productivity and Performance Management, 56(5/6), 436-455.

Cha, J. (2011). Exploring the internet as a unique shopping channel to sell both real and virtual items: a comparison of factors affecting purchase intention and consumer characteristics. Journal of Electronic Commerce, 12 (2), 115 132.

Chatterjee, P. (2010). Multiple-channel and cross-channel shopping behavior: Role of consumer shopping orientations. Marketing Intelligence \& Planning,28 (1), 9-24.

Childers, T. L., Carr, C. L., Peck, J., and Carson, S. (2001). Hedonic and utilitarian motivations for online retail shopping behavior. Journal of Retailing, 77(4), 511-535.

Chocarro, R., Cortiñas, M., and Villanueva, M. L. (2013). Situational variables in online versus offline channel choice. Electronic Commerce Research and Applications, 12(5), 347-361.

Davis, F. D. (1989). Perceived usefulness, perceived ease-of-use, and user acceptance of information technology. MIS Quarterly, 13, 319-339.

Deci, E. L., and Ryan, R. M. (1985). Intrinsic motivation and self-determination in human behavior. Springer Science \& Business Media.

Dholakia, U.M., Kahn, B.E., Reeves, R., Rindfleisch, A., Stewart, D. and Taylor, E. (2010). Consumer behaviour in a multichannel, multimedia retailing environment. Journal of Interactive Marketing, 24, 86-95.

Ganesh, J., Reynolds, K. E., Luckett, M., and Pomirleanu, N. (2010). Online shopper motivations, and e-store attributes: an examination of online patronage behavior and shopper typologies. Journal of Retailing, 86 (1), 106115.

Ha, J. and Stoel, L. (2009). Consumer E-Shopping Acceptance: Antecedents in a Technology Acceptance Model”. Journal of Business Research, 62 (5), 565-571.

Herrero Crespo, A., and Rodriguez del Bosque, I. (2010). The influence of the commercial features of the Internet on the adoption of e-commerce by consumers. Electronic Commerce Research and Applications, 9(6), 562-575.

Homburg, C., Vollmayr, J., and Hahn, A. (2014). Firm value creation through major channel expansions: evidence from an event study in the United States, Germany, and China. Journal of Marketing, 78(3), 38-61.

Jones, C., and Kim, S. (2010). Influences of retail brand trust, off-line patronage, clothing involvement and website quality on online apparel shopping intention. International Journal of Consumer Studies, 34(6), 627-637.

Keen, C., Wetzels, M., De Ruyter, K., and Feinberg, R. (2004). E-tailers versus retailers: Which factors determine consumer preferences. Journal of Business Research, 57(7), 685-695.

Knox, G.A. (2005). Modelling and Managing Customers in a Multichannel Setting. PhD Dissertation. University of Pennsylvania.

Konuş, U., Verhoef, P.C., and Neslin, S.A. (2008). Multichannel shopper segments and their covariates. Journal of Retailing, 84 (4) 398-413. 
Kressmann, F., Sirgy, M.J., Herrmann, A. and Huber, F. (2006). Direct and indirect effects of self-image congruence on brand loyalty. Journal of Business Research, 59: 955-964

Kumar, V. and Venkatesan, R. (2005). Who are the multichannel shoppers and how do they perform? Correlates of multichannel shopping behaviour. Journal of Interactive Marketing, 19 (2), 44-62.

Kushwaha, T., and Shankar, V. (2007). Single Channel vs. Multichannel Customers: Determinants and Value to Retailers. Working paper, Texas A\&M University.

Kushwaha, T., and Shankar, V. (2013). Are multichannel customers really more valuable? The moderating role of product category characteristics. Journal of Marketing, 77(4), 67-85.

Liang, T. P., and Huang, J. S. (1998). An empirical study on consumer acceptance of products in electronic markets: a transaction cost model. Decision support systems, 24(1), 29-43.

Maity, D., and Arnold, T. J. (2013). Search: An Expense or an Experience? Exploring the Influence of Search on Product Return Intentions. Psychology \& Marketing, 30(7), 576-587.

Mathwick, C., and Rigdon, E. (2004). Play, flow, and the online search experience. Journal of Consumer Research, 31(2), 324-332.

McGoldrick, P.J. and Collins, N. (2007). Multichannel retailing: profiling the multichannel shopper. The International Review of Retail, Distribution and Consumer Research, 17 (2), 139-158.

Montoya-Weiss, M. M., Voss, G. B., and Grewal, D. (2003). Determinants of online channel use and overall satisfaction with a relational, multichannel service provider. Journal of the Academy of Marketing Science, 31(4), 448-458.

Nelson, P. (1970). Information and consumer behavior. The Journal of Political Economy, 311-329.

Neslin, S. A., Grewal, D., Leghorn, R., Shankar, V., Teerling, M. L., Thimas, J. S., and Verhoef, P. C. (2006). Challenges and opportunities in multichannel customer management. Journal of Service Research, 9 (2) 95-112.

Neslin, S.A. and Shankar, V. (2009). Key issues in multichannel customer management: current knowledge and future directions. Journal of Interactive Marketing, 23, 70-81.

O’Neill, S., and Chu, J. (2001). Online returns management strategies. IBM Global Service eStrategy Report. Accessed online 03/11/2014: http://www-935.ibm.com/services/uk/igs/pdf/esr-online-returns-management.pdf

ONS (2015). Internet Access. Households and individuals, available at http://www.ons.gov.uk/ons/rel/rdit2/internet-access---households-and-individuals/2014/stb-ia2014.html (accessed 22 July 2015).

Ontsi (2015). Indicadores destacados de la sociedad de la información, available at http://www.ontsi.red.es/ontsi/sites/default/files/indicadores_destacados_mayo_2015.pdf. (accessed 22 July 2015).

Overby, J. W., and Lee, E. J. (2006). The effects of utilitarian and hedonic online shopping value on consumer preference and intentions. Journal of Business Research, 59(10), 1160-1166.

Peterson, R.A., Balasubramanian, S., and Bronnenberg, B.J. (1997). Exploring the Implications of the Internet for Consumer Marketing. Journal of the Academy of Marketing Science, 25, 329-346.

PwC (2014). PwC Global Online Shopping Habits. Accessed online 03/11/2014 http://www.pwc.com/gx/en/retailconsumer/retail-consumer-publications/global-multi-channel-consumer-survey/index.jhtml

Rangaswamy, A. and van Bruggen, G. H. (2005). Opportunities and challenges in multichannel marketing: an introduction to the special issue. Journal of Interactive Marketing, 19(2), 5-11.

Rose, S., Clark, M., Samouel, P. and Hair, N. (2012). Online customer experience in e-retailing: an empirical model of antecedents and outcomes. Journal of Retailing, 88 (2), 308-322.

Salisbury, W.D., Pearson, R.A., Pearson, A.W., and Miller, D.W. (2001). Perceived Security and World Wide Web Purchase Intention. Industrial Management \& Data Systems, 101 (4), 165-76.

Schröder, H., and Zaharia, S. (2008). Linking multi-channel customer behavior with shopping motives: An empirical investigation of a German retailer. Journal of Retailing and Consumer Services, 15(6), 452-468.

Shang, R. A., Chen, Y. C., and Shen, L. (2005). Extrinsic versus intrinsic motivations for consumers to shop online. Information \& Management, 42(3), 401-413. 
Tauber, E. M. (1972). Why do people shop?. The Journal of Marketing, 36 (4), 46-49.

Teo, T. S., Lim, V. K., and Lai, R. Y. (1999). Intrinsic and extrinsic motivation in Internet usage. Omega, 27(1), $25-37$.

Teo, T. S., and Yu, Y. (2005). Online buying behavior: a transaction cost economics perspective. Omega, 33(5), 451-465.

Thomas, J. S., and Sullivan, U. Y. (2005). Managing marketing communications with multichannel customers. Journal of Marketing, 69 (4), 239-251.

To, P. L., Liao, C., and Lin, T. H. (2007). Shopping motivations on Internet: A study based on utilitarian and hedonic value. Technovation, 27(12), 774-787.

Vallerand, R.J. (1997). Toward a Hierarchical Model of Intrinsic and Extrinsic Motivation, in Advances in Experimental Social Psychology, M. Zanna (ed.), Academic Press, New York, 271-360.

Van der Heijden, H. (2004). User acceptance of hedonic information systems.MIS quarterly, 695-704.

Venkatesh, V. (2000). Determinants of perceived ease of use: Integrating control, intrinsic motivation, and emotion into the technology acceptance model. Information systems research, 11(4), 342-365.

Venkatesh, V., Morris, M. G., Davis, G. B., \& Davis, F. D. (2003). User acceptance of information technology: Toward a unified view. MIS quarterly, 425-478.

Venkatesan, R, Kumar, V., and Ravishanker, N. (2007). Multichannel Shopping: Causes and Consequences. Journal of Marketing, 71 (2), 114-32.

Verhoef, P. C., Neslin, S. A. and Vroomen, B. (2007). Multichannel customer management: Understanding the research-shopper phenomenon. International Journal of Research in Marketing, 24(2), 129-148.

Wallace, D. W., Giese, J. L., and Johnson, J. L. (2004). Customer retailer loyalty in the context of multiple channel strategies. Journal of Retailing, 80(4), 249-263.

Webloyalty (2014). España aprueba con nota el perfil del "Comprador Online Europeo 2013"- Accessed online $03 / 11 / 2014$

http://webloyalty.es/News_noviembre_2013_espana_aprueba_con_nota_el_perfil_del_rcomprador_online_eur opeo 2013

Wolfinbarger, M., and Gilly, M. C. (2001). Shopping online for freedom, control, and fun. California Management Review, 43(2), 34-55

Zhang, J., Farris, P. W., Irvin JW, Kushwaha, T., Steenburgh, T.J. and Weitz, B.A. (2010). Crafting Integrated Multichannel Retailing Strategies. Journal of Interactive Marketing, 24, 168-180. 